\title{
Identification of groundwater exfiltration, interflow discharge and hyporheic exchange flows by fiber-optic distributed temperature sensing supported by electromagnetic induction geophysics
}

J. Gaona (1) https://orcid.org/0000-0002-6611-9173, K. Meinikmann, J. Lewandowski (1) https://orcid.org/0000-0001-5278-129X

DOI

10.1002/hyp.13408

Original publication date

05 February 2019

Document version

Accepted version

Published in

Hydrological Processes

Citation (Vancouver)

Gaona J, Meinikmann K, Lewandowski J. Identification of groundwater exfiltration, interflow discharge and hyporheic exchange flows by fiber-optic distributed temperature sensing supported by electromagnetic induction geophysics. Hydrological Processes. 2019. doi: 10.1002/hyp.13408 


\title{
Identification of groundwater exfiltration, interflow discharge and hyporheic exchange flows by fiber-optic distributed temperature sensing supported by electromagnetic induction geophysics
}

\author{
J. Gaona ${ }^{1,2,3}$, K. Meinikmann ${ }^{1}$, J. Lewandowski ${ }^{1,4}$
}

${ }^{1}$ Leibniz Institute of Freshwater Ecology and Inland Fisheries (IGB), Müggelseedamm 310, 12587, Berlin, Germany. ${ }^{2}$ Freie Universität Berlin, Dahlem Research School, Hittorfstraße 16, 14195, Berlin, Germany. ${ }^{3}$ University of Trento, Department of Civil, Environmental and Mechanical Engineering, Via Messiano 77, 31123, Trento, Italy. ${ }^{4}$ Humboldt University Berlin, Faculty of Mathematics and Natural Sciences, Geography Department, Rudower Chaussee 16, 12489 Berlin, Germany.

Corresponding author: Jaime Gaona Garcia (gaona@igb-berlin.de)

\begin{abstract}
Water exchange across the sediment-water interface of streams impresses a characteristic thermal pattern at the interface. The use of Fiber Optic Distributed Temperature Sensing (FODTS) at the sediment-water interface in a small sand-bed stream identifies such temperature patterns. Groundwater and interflow can be differentiated based on the temporal evolution of temperature patterns. Additionally, sudden temperature changes at the sediment-water interface observed during the transit of floods enable spatial identification of local up- and downwelling. Electromagnetic induction geophysics (EMI) can detect subsurface texture structures that support groundwater-surface water exchange. Our results show that areas of permanent temperature anomalies observed with FO-DTS match areas of comparatively homogeneous electrical conductivity. This indicates groundwater discharge and enables differentiating groundwater discharge from interflow and local downwelling.
\end{abstract}

Keywords: Fiber optic distributed temperature sensing; groundwater exfiltration; interflow discharge; hyporheic exchange flow; temperature anomaly; flood; electromagnetic induction geophysics; sediment structure.

\section{Acknowledgements}

This research is funded by the SMART (Science for MAnagement of Rivers and Tidal systems) Joint Doctoral Erasmus Mundus Programme, funded by the European Commission, SGA 2015-1628. This publication reflects the views only of the authors, and the Commission cannot be held responsible for any use which may be made of the information contained therein. We thank Christine Sturm, Anne Mehrtens, Wiebke Seher, Jason Galloway, Hannah Schulz and Birgit Müller for their help with fieldwork and specially Amaia Marruedo and Silvia Folegot for their FO-DTS training, as well as the Nature Park Schlaubetal for allowing access to River Schlaube. We must extend our gratitude to Fernando A. Monteiro Santos (University of Lisbon) for the invaluable insights he shared about the accurate procedure to survey and process EMI data. Finally, we thank two anonymous reviewers whose comments/suggestions helped to improve and clarify the present manuscript.

This article has been accepted for publication and undergone full peer review but has not been through the copyediting, typesetting, pagination and proofreading process which may lead to differences between this version and the Version of Record. Please cite this article as doi: 10.1002/hyp.13408 


\section{Introduction}

The sediment-water interface (SWI) is one of the crucial interfaces in the water cycle. There, water exchange determines environmentally important chemical and biological processes (Lewandowski, Angermann, Nützmann, \& Fleckenstein, 2011). The interface underlying streams where groundwater and surface water mix and which contains variable portions of surface water (SW) and groundwater $(\mathrm{GW})$ is called hyporheic zone (HZ). Flow in this zone is termed hyporheic exchange flow (HEF). HEF is exchange across the streambed in both directions. Water flowing in the stream channel flows into the subsurface (downwelling), in the hyporheic zone and then returns to the stream (upwelling) (Bencala, 2005; Winter, 1998). While groundwater exfiltration originates in the saturated zone, interflow is the lateral movement of water in the unsaturated zone. Interflow occurs when water infiltrates into the subsurface, hydraulic conductivity decreases with depth, and lateral flow proceeds downslope (Lyon, Trimble, \& Ward, 2004). Both, groundwater and interflow might enter the hyporheic zone, and might discharge into the SW as portion of the HEF.

Studying downwelling, upwelling, GW exfiltration and interflow discharge is challenging. A powerful approach is the use of temperature as a tracer of water exchange (Anderson, 2005; Constantz \& Stonestrom, 2003). GW and interflow have temperature regimes defined by climatic conditions while SW temperatures respond to weather conditions and additionally to the percentage share of its runoff components. GW exfiltration, interflow discharge and local upwelling and downwelling leave source-specific spatially and temporally variable temperature patterns at the SWI which we call "thermal footprint". To cope with the spatial heterogeneity of the exchange either laborious point or distributed measurement techniques such as fibre optic distributed temperature sensing (FO-DTS) are required.

FO-DTS is capable of mapping temperature variations at the SWI based on the temperature-dependent (Raman) backscattering of a laser pulse in the fibre optic cable used as distributed sensor (Dakin, 1987). First, FO-DTS was applied in lakes (Selker et al., 2006a) and later on in rivers (Selker et al., 2006a; Westhoff et al., 2007) and other water bodies such as wetlands (Lowry, Walker, Hunt, \& Anderson, 2007) to study GW-SW interactions. Multilinear layouts of the fibre optic cable provide valuable 2D information about location, shape and scale of HEF patterns (Blume, Krause, Meinikmann, \& Lewandowski, 2013;

Mwakanyamale, Slater, Day-Lewis, Elwaseif, \& Johnson, 2012) taking advantage of the submeter resolution of FO-DTS (Henderson, Day-Lewis, \& Harvey, 2009). This high resolution provided by FO-DTS applied in a 3D layout even enabled investigation on thermal transport in the hyporheic zone (Shanafield, McCallum, Cook, \& Noorduijn, 2016). Recent studies combining FO-DTS with other techniques such as piezometers, temperature-depth profiles or ground penetrating radar revealed a large potential of such combinations for studies of GWSW exchange in complex environments (Briggs, Lautz, \& McKenzie, 2012a; GonzálezPinzón et al., 2015; Hare, Briggs, Rosenberry, Boutt, \& Lane, 2015). Geophysical techniques are particularly powerful to explore the geologic variability of the riverbed controlling GWSW exchange (Hare et al., 2017; Slater et al., 2010).

In contrast to other geophysical techniques such as electrical resistivity imaging (ERI) or georadar (Crook et al., 2006; Day-Lewis et al., 2006), there are few EMI applications in stream sediments (Binley et al., 2013; Gourry, Vermeersch, Garcin, \& Giot, 2003; Mansoor, Slater, Artigas, \& Auken, 2006; Rosenberry, Briggs, Voytek \& Lane, 2016) despite its advantages for quick and economic exploration of subsurface structures (Robinson et al., 2008). Advantages of EMI compared to ERI are its readiness and flexibility to explore large subsurface areas in detail without requiring much manpower, resources or time. 
The physics of the EMI technique consist on the induction of a magnetic field that creates a secondary electromagnetic field in the sediment. The phase shift of the secondary magnetic field (quadrature) recorded back in the device is inverted to provide electrical conductivity results depending on pore water composition and sediment texture (Boaga, 2017). The depth of investigation depends on the excitation frequency or/and the separation of the electromagnetic coils (Binley et al., 2013). EMI helps to differ between fine and coarse sediment based on differences of electrical conductivity (Lesch, Corwin, \& Robinson, 2005) under the prerequisite that pore water conductivity and other conductivity variations of sediment (clay) are negligible compared to the texture range of the streambed.

The present study applies a multi-linear 2D layout of FO-DTS to identify the intensity and spatial distribution of the different HEF components ((a) GW exfiltration, (b) interflow discharge and (c) local down-/upwelling of SW) by capturing temperature maps of the SWI. In addition, similarly to the works of Rosenberry et al. (2016) at coarse-grained fluvial settings, we test the potential of EMI geophysics for exploring the subsurface structures of a heterogeneous sandy stream to support the interpretation of GW-SW exchange based on the thermal footprints observed with FO-DTS.

\section{Materials and methods}

\subsection{Study site}

The study site is located at the upper River Schlaube, a second-order stream in Brandenburg, Germany (Figure 1a). The study reach is located in a funnel glacial valley carved in a plateau of sandy materials. The depressed location of the river (altitude contrast $30-50 \mathrm{~m}$ ) results in high piezometric heads. Multiple permanent springs can be observed along the river banks in areas upstream and downstream of the study site. These springs indicate a close connection between interflow, groundwater and SW. The average width of the river is approximately $4 \mathrm{~m}$ and the slope of the river is $\mathrm{s}=0.005 \mathrm{~m} / \mathrm{m}$ at the study site (Figure 1b). The streamflow shows only small variations because it is naturally regulated by Lake Wirchensee located $1400 \mathrm{~m}$ upstream of the study site. The measured flow regime (Table 1) during our study oscillated between 18 and $35 \mathrm{~L} / \mathrm{s}$.

At the $45 \mathrm{~m}$ long reach of the study site diverse hydro-geomorphologic sections (straight, meandering and multi-channel) with different riverbed structures (planar sections, riffle-pool and bars) exist. Based on these geomorphic changes of the stream, we define four transects (Figure 1b). TR1 is located where the stream shows a main straight channel of quick current and a muddy meandering secondary channel of slow flow reincorporated to the main channel a few meters downstream. TR2 pinpoints the area where a fallen log isolates the left side of the channel from the current, which remains flooded depending on the stream level. TR3 is located downstream a narrow section of the stream, between a pool and riffle sequence. TR4 covers a sandy point bar in the last curve of the study site. There is a variety of sediment textures (from clean gravels to fine organic deposits, with hydraulic conductivities between $2.43 \cdot 10^{-4} \mathrm{~m} / \mathrm{s}$ and $2.31 \cdot 10^{-6} \mathrm{~m} / \mathrm{s}(21 \mathrm{~m} / \mathrm{d}$ and $0.2 \mathrm{~m} / \mathrm{d})$ of the uppermost sediment layers). Woody debris is present in the streambed.

2.2. Fibre optic distributed temperature sensing

FO-DTS was applied to distinguish GW exfiltration, interflow discharge and local up/downwelling of SW contributing to the thermal patterns observed at the SWI. Details about FO-DTS operation for river thermal investigation can be found elsewhere (e.g. Selker et al., 2006a; Tyler et al., 2009). Figure 1b visualizes the 2D-layout of the FO-DTS cable in 10 parallel lines deployed along a river reach of $\approx 50 \mathrm{~m}$ in length. The lines were transversally 
separated 20-50 cm depending on the stream's width. $590 \mathrm{~m}$ fibre optic cable (Brugg BRUusens 2 x MMF metallic armoured $4.6 \mathrm{~mm}$ Red 25/125 nm) were buried 3-8 cm deep in the sediment to measure SWI temperatures instead of SW temperatures (Krause, Blume, \& Cassidy, 2012; Lowry et al., 2007). Only in case of obstacles, such as roots or logs, the cable emerged from the sediment and was in contact with SW or air. The depth of the cable in the sediment was qualitatively monitored by plastic ties of known length fixed to the cable to account for scouring and sediment deposition. Two loops of $25 \mathrm{~m}$ length at each end of the cable submerged in a mixed ice-bath were used to conduct the calibration of the control unit Silixa Ultima (Silixa Ltd., Hertfordshire, UK).

The cable was operated in a single-ended mode in both directions. The FO-DTS system has a spatial resolution of $\approx 0.3 \mathrm{~m}$ and achieves a temperature resolution $<0.05{ }^{\circ} \mathrm{C}$ for measurement durations of 4 to 5 minutes. Measurements analyzed in the present study where conducted especially in summer and winter when temperature contrasts between GW and SW were largest $\left(3-6^{\circ} \mathrm{C}\right)$, i.e. on $25 \mathrm{Jul} 2016$, $15 \mathrm{Sep} 2016$, 18 Jan 2017, plus the $48 \mathrm{~h}$ long period between $1 \mathrm{Jul} 2017,0: 00 \mathrm{~h}$ and $2 \mathrm{Jul}$ 2017, 24:00 h (Table 1). The measurement periods covered diverse weather, streamflow, interflow and GW conditions (Figure 2).

The cable location was georeferenced by a tachymetric survey with a Leica TPS1200 (Leica Geosystems AG, Hesse, Germany). To define start and end points of each DTS line in the raw measurement file, start and end points of each line, as well as other intermediate relevant points along the fibre, were manually warmed. The other relevant points included areas in contact with air or stream water. Some of the sections of the cable in contact with streamflow were used as references of SW temperatures while sections in contact with the atmosphere were eliminated from the dataset (e.g. 'Log' areas in Figures 2 \& 3).

In addition to FO-DTS, pressure data loggers Schlumberger Mini-Diver ${ }^{\mathrm{TM}}$ (Schlumberger Ltd., Texas, USA) monitored GW (filter screen $70 \mathrm{~cm}$ below the SWI) and SW pressure heads at Transects TR1 and TR3 (Figure 1b). At those two transects, streamflow velocity and cross-sectional bed morphology were additionally measured with the electromagnetic sounder OTT-MFpro (OTT Hydromet GmbH, Austria) to calculate streamflow. Air and SW temperatures were recorded with HOBO Tidbitv2 ${ }^{\mathrm{TM}}$ data loggers (Onset Computer Coorp., Massachusetts, USA). Furthermore, we took sediment samples of the upper $5 \mathrm{~cm}$ of the streambed 0.5 to $1 \mathrm{~m}$ downstream of each transect to determine hydraulic and thermal properties of the hyporheic sediment (Table 1). An additional Tidbit2 ${ }^{\mathrm{TM}}$ data logger measured GW temperature at the source of the strongest spring upstream of the study site.

2.2.1 Identification of groundwater and interflow discharge from SWI temperature anomalies

Lowry et al. (2007) first proposed the identification of GW discharge based on temperature anomalies and their temporal variability at the SWI. The authors demonstrate how the interpretation of temperature anomalies facilitates identifying areas of diffuse and focused groundwater discharge. Krause et al., (2012) also localizes water discharge at the SWI with temperature anomalies $A_{T}\left(S W I_{i}\right)\left({ }^{\circ} \mathrm{C}\right)$ and describes additional indicators for temporal analysis. In the present study, the temperature anomaly $A_{T}\left(S W I_{i}\right)$ of any point $i$ along the fibre buried in the sediment is calculated by subtracting the spatially averaged SW temperature $\overline{T(S W)}\left({ }^{\circ} \mathrm{C}\right)$ from the measured SWI temperature at point $i T\left(S W I_{i}\right)\left({ }^{\circ} \mathrm{C}\right)$ (Equation 1). The $\overline{T(S W)}$ used as reference is averaged from 15 measurement points along $2 \mathrm{~m}$ of Line 2 of the setup, upstream of transect TR3 (Figure 1), where the fibre lies unburied over roots in full contact with SW. The quick and deep current of the stream where Line 2 remains unburied ensures intensive mixing of the SW supporting the representativeness of the 
measured SW temperatures. This approach also enables identifying interflow discharge by analysis of SWI temperatures in the margins.

$$
\text { Eq. } 1 \quad A_{T}\left(S W I_{i}\right)=T\left(S W I_{i}\right)-\overline{T(S W)}
$$

$\mathrm{A}_{\mathrm{T}}\left(\mathrm{SWI}_{\mathrm{i}}\right), \mathrm{T}\left(\mathrm{SWI}_{\mathrm{i}}\right)$ and $\overline{\mathrm{T}(\mathrm{SW})}$ values are calculated for every 5 minutes measurement interval. Table 2 summarizes the use of $A_{T}$ to identify areas of the SWI influenced either by GW exfiltration or interflow discharge. Groundwater discharge occurs in areas with year to seasonal persistence of temperature anomalies. The temporal evolution of temperature anomalies at time scales from hours to weeks is used to identify interflow discharge after heavy rainfalls.

The areas attributed to $\mathrm{GW}$ and interflow discharge based on their distinct temperature anomalies are labelled according to the source of water identified on them $(\mathrm{GW}$ : groundwater, INTF: interflow) and their transect location. Other areas take the name of the observed hydrologic state such as emerged (Ei) or stagnated waters ( $\mathrm{Si}$ ). In this way, GW3 means an area of temperature anomaly attributed to GW discharge located at transect 3. Being $i=$ the transect where they are located, $i=i-j$ means located between two transects.

\subsubsection{Identification of small-scale downwelling patterns based on small flood events}

Natural flood events in River Schlaube are rare due to the strong regulating effect of upstream located lakes and the dense forest canopy in the basin. Despite the steady nature of the streamflow, we noticed several small peaks and periods of slightly increased SW levels in the recorded surface water level time series. In order to distinguish which periods of increased flow can be considered floods, we calculated the seasonal, trend and random components of the surface water level time series averaged at daily time steps. We obtained standard deviations of $2.35 \mathrm{~cm}, 0.35 \mathrm{~cm}$ and $0.67 \mathrm{~cm}$, respectively, for the seasonal, trend and random components (R package "stats v.3.5.1", function "decompose" based on Kendall, Stuart \& Ord (1983)). Moreover, the comparison of the random component with the rainfall time series points out differences attributable to artificial flow operation, especially during periods of summer baseflow. Indeed, the cause of these surface water level fluctuations was the operation of a weir at the outflow of the upstream located lake, an infrastructure capable of triggering man-made flood pulses. Artificial flood events caused by an increased discharge from the warm, upstream located lake cause a peak of increased SW temperatures quickly propagating downstream (Watson, Cardenas, Ferencz, Knappett \& Neilson, 2018). As soon as the thermal peak reaches the study site, SW temperatures increase abruptly. SW temperatures propagate particularly fast into the sediment where significant SW downwelling takes place (Cardenas \& Wilson, 2007).

The artificial events included in the present study show water level rises of $2.5 \mathrm{~cm}, 4$ $\mathrm{cm}$ and $5 \mathrm{~cm}$ in less than 20 minutes. These level rises represent flood events of respectively $3.7,6$ and 7.5 times the standard deviation of the natural daily random component. The spatial and temporal analysis of the abrupt temperature changes occurring in certain areas of the shallow streambed enables the localization of local SW downwelling. We propose the identification of areas of local SW downwelling based on the different resilience of particular regions of the SWI to temperature change induced by artificial flood events. The spatially variable temperature changes at the SWI can be mapped as rates of temperature change $\Delta T / \Delta t$ $\left({ }^{\circ} \mathrm{C} / \mathrm{h}\right)$ during each time step $\Delta t$. The delineation of down-/upwelling areas is based on their respective resilience to flood-induced temperature changes. Downwelling areas show fast adaption towards high values of $\Delta T / \Delta t$ during flood conditions. Upwelling areas experience little change in $\Delta T / \Delta t$ both under baseflow and flood conditions. 
In summer the forest canopy causes a mosaic of sunlight reaching the valley bottom. The analysis of $\Delta T / \Delta t$ caused by this mosaicked radiation during the period prior to each flood's arrival allows defining a threshold between the range of $\Delta T / \Delta t$ caused by radiation and the one determined by the sudden warming due to the flood. We define that the 95percentile of the $\Delta T / \Delta t$ observed during the steady state before the flood $\left(\Delta T / \Delta t_{95 \%}\right)$ defines the positive threshold for $\Delta T / \Delta t$ caused by radiation, the main source of heat affecting the SWI under steady conditions. The assumption implies that $\Delta T / \Delta t>\Delta T / \Delta t_{95} \%$ are caused by a heat source (e.g. SW inflow) different from radiation with a $95 \%$ confidence interval. Downwelling areas, where SW infiltration prevails, should show $\Delta T / \Delta t>\Delta T / \Delta t_{95 \%}$ while upwelling areas should remain below the threshold.

\subsection{Subsurface exploration using EMI geophysics}

EMI exploration of the subsurface was conducted in four longitudinal transects of $\approx$ $50 \mathrm{~m}$ length that follow the curvature of the river which is constrained by the slopes (Figure 1). We used a CMD Explorer (GF Instruments, Brno, Czech Republic) for surveying the longitudinal transects in manual mode in steps separated $0.6 \mathrm{~m}$. Multi-depth low induction number devices such as the CMD-Explorer have multiple receiver coils separated from the transmitter coil (Villeneuve, Cook, Shanafield, Wood, \& White, 2015) operating at the same frequency. Low induction number electromagnetic devices of unique-frequency operate a linear calibration applicable at low to moderate ranges of electrical conductivity of subsurface materials $(\leq 100 \mathrm{mS} / \mathrm{m})$ (Brosten, Day-Lewis, Schultz, Curtis, \& Lane, 2010).

The limited GPS positioning capabilities under dense forest canopy forced to locate the CMD locations with the total station Leica TPS 1200 which lasted at least 10 seconds per location. Thus, we chose a measurement time of $10 \mathrm{~s}$ also for the CMD Explorer. The device enables a theoretical exploration depth of approximately $6 \mathrm{~m}$ with the horizontal coplanar configuration (full-depth range). On-the-fly 1D inversion of the apparent electrical conductivity is provided by the CMD Explorer. However, RES2Dinv (Geotomo Software SDN BHD, Malaysia) has been used for the 2D inversion of the data. The EMI data were loaded into the software as a fictional electrical resistivity survey configured in a pole-pole array (type 6) according to the CMD's manual. From the multiple parametrization options of the software, we adopted the finite-difference mode to calculate the apparent resistivity. We have chosen the non-linear smoothness-constrained least-squares optimization technique (L2 norm) (Loke, Acworth, \& Dahlin, 2003) regarding the assumed smooth transition from low to high values of resistivity in a streambed without identified bedrock. The model achieves this smoothing by minimizing the square of the changes in resistivity (L2 norm). The range of dampening factors is assumed 0.01-0.1 with initial values of 0.1 . The horizontal flatness filter ratio used was 1; no diagonal filter was used. The option of the finest node configuration of 4 nodes in between electrodes was chosen. The layer depth definition of the mesh increases with depth from $0.05 \mathrm{~cm}$ in the upper layers to $1 \mathrm{~m}$ in the lower ones. The convergence limit was set to $3 \%$ after 4 iterations. The software provides RMS error fit and noise statistics.

EMI response depends on electrical conductivity (EC) of pore water, sediment structure/texture, and water saturation. Below the streambed the latter is $100 \%$, i.e. constant and thus negligible. For the correct interpretation of the EMI data, the electrical conductivity of the pore water is required to assure that difference of electrical conductivity observed with EMI are due to subsurface texture changes and not due to different pore water EC. Therefore, we collected 80 pore water samples from the eight different depths of the ten multi-level piezometers (Table 1) located at the four transects. Unfortunately, soils with clay content may invert the proportional relation between EC and porosity and the associated hydraulic 
conductivity (Slater \& Lesmes, 2002). Sediment coring with a 1.5 m Pürckhauer type auger (Table 1) was conducted to unveil subsurface clay deposits taking advantage of the fact that clays remain in this narrow corer type while sandy and coarser materials tend to be lost in the overlying water column during retrieval of the corer.

\section{Results and discussion}

\subsection{FO-DTS-based identification of groundwater and interflow discharge}

Areas GW3 and GW4 (Figure 2a-c) show persistent positive temperature anomalies $A_{T}$ of up to $3.5^{\circ} \mathrm{C}$ (hot spots) during winter and negative $A_{T}$ down to $-3.5^{\circ} \mathrm{C}$ (cold spots) in summer. Both regions experience small variations of their area $(\triangle A r e a= \pm 21 \%$ at GW3 and $\pm 15.5 \%$ at GW4) and average temperature anomaly $\left(\Delta\left|A_{T}\right|= \pm 0.4{ }^{\circ} \mathrm{C}\right.$ at $\mathrm{GW} 3$ and $\pm 0.26{ }^{\circ} \mathrm{C}$ at GW4 during baseflow conditions the 15 Sep 2016 and 18 Jan 2017, Figure 2a \& b). Note that the delineation of area is temporally changing and thus the number of averaged values of the temperature anomalies is also varying. Conversely, the increase of the areas during the periods after rainfall ( 2 Jul 2017, Figure 2c) reaches $\triangle$ Area $=+176 \%$ of the baseflow area at GW3 and $+140 \%$ at GW4. The increase of the temperature anomaly in these circumstances becomes $\Delta A_{T}=-1.36{ }^{\circ} \mathrm{C}$ at GW3 and $-0.83{ }^{\circ} \mathrm{C}$ at GW4. Pressure transducers at Transects 3 and 4 , respectively (Figure 1), indicate higher piezometric heads of subsurface water compared to SW. Area GW3 at TR3 is located in a pool. It is well known that groundwater discharge is diverted to such pool areas by hyporheic flow paths (Cardenas \& Wilson, 2007). As described by Kasahara and Hill (2007b), the downstream part of convex shorelines as they occur at GW3 and at GW4 result in increased GW discharge from the riparian aquifer. These findings support that GW discharge causes the temperature anomalies at GW3/GW4.

Areas INTF2 and INTF3 show temporary cold $A_{T}$ (independent of the season (Figure 2a-c)) that increase sharply both in intensity and extent in the hours to days after rain events and progressively fade away within days (Figure 3d-g). The spatial extent of INTF2 and INTF3 increases significantly (more than four times for INTF2 and almost two times for INTF3) from its minimum extent at dry weather to a maximum extent during periods of and shortly after periods of precipitation (15 Sept 2016, Figure 2a vs. 2 Jul 2016, Figure 2c, Figure $3 \mathrm{e}-\mathrm{g}$ ). The average temperature anomaly $A_{T}$ in INTF2 increases from $-0.07{ }^{\circ} \mathrm{C}$ (almost non-existent) during dry periods to $-1.57{ }^{\circ} \mathrm{C}$ during wet periods. In INTF3, $A_{T}$ is $-0.17{ }^{\circ} \mathrm{C}$ during dry periods and $-1.79{ }^{\circ} \mathrm{C}$ during wet periods. The pulse-like discharge pattern after rain events followed by flow recession shown in Lines 1 and 2 of Figure 3e, f, g indicates that shallow interflow discharge is the driving force of the temperature anomaly at INTF2 for those lines. The lack of clear correlation between $A_{T}$ and environmental conditions such as air temperature or river stage fluctuations supports the interflow origin, too. Visually identified springs on the streambank after periods of precipitation are a further support of the occurrence of intense interflow at the study site.

Emerged areas (Ei) and areas of stagnant water ( $\mathrm{Si}$ ) show larger values of $A_{T}\left(>3{ }^{\circ} \mathrm{C}\right)$ than INTF2/INTF3 during days of large daily temperature amplitudes (e.g. 15 Sep 2016, Figure 2a, or 18 Jan 2017, Figure 2b). Additionally, the anomalies disappear partly during night time (Figure 2d). Probably radiation is the driving force of the observed temperature anomalies. E1, E1-2, E2 are temporarily emerged areas depending on SW levels while S1, S2-3, S3-4 comprise pools of stagnant water. The temporal disconnection of E1, E1-2 and E2 from the streamflow and the shallow slow flow at S1, S2-3, S3-4 favour the increasing relevance of radiation on their thermal response and explains the large value of $A_{T}$. Table 2 summarizes how to distinguish different types of subsurface discharge at the SWI based on 
ranges of $A_{T}\left(S W I_{i}\right)$, and additionally, the ranges observed for emerged/stagnant areas showing the daily temperature cycle of $A_{T}\left(S W I_{i}\right)$ due to solar radiation.

\subsection{FO-DTS differentiation of local SW down-/upwelling during flood events}

Three flood events were measured with FO-DTS (Table 2, Figure 4a-f). Flood events raised both SW temperatures (Figure 4) and SWI temperatures; the latter in some areas up to $1.4^{\circ} \mathrm{C}$ within 20 minutes $\left(\Delta T / \Delta t 3-5^{\circ} \mathrm{C} / \mathrm{h}\right.$ ) (Figure $4 \mathrm{~b}, \mathrm{~d}, \mathrm{f}$ ). We calculated the threshold $\Delta T / \Delta t_{95 \%} \approx 1^{\circ} \mathrm{C} / \mathrm{h}$ (Figure $4 \mathrm{a}, \mathrm{c}, \mathrm{e}$ ) under baseflow conditions based on the periods shortly before floods in which radiation is the main source of warming $\left(1.4^{\circ} \mathrm{C} / \mathrm{h}\right.$ on $25 \mathrm{Jul} 2016,0.8$ ${ }^{\circ} \mathrm{C} / \mathrm{h}$ on $2 \mathrm{Jul} 2017,0.9^{\circ} \mathrm{C} / \mathrm{h}$ on $3 \mathrm{Jul} 2017$, Figure $\left.4 \mathrm{~b}, \mathrm{~d}, \mathrm{f}\right)$. The threshold distinguishes the warming due to floods from the range of warming caused by the ubiquitous impacts of solar radiation and air temperature fluctuation. Additionally, areas of the SWI experiencing $\Delta T / \Delta t$ $<1{ }^{\circ} \mathrm{C} / \mathrm{h}$ both during baseflow and flooding conditions correspond to the areas GW3/GW4 of prevalent groundwater upwelling.

The flood from 25 Jul 2016 exhibits the largest overall increase of both SW level and SW temperature $\left(5 \mathrm{~cm}\right.$ and $\left.1.4{ }^{\circ} \mathrm{C}\right)$ among the three floods (Figure $\left.4 \mathrm{~b}\right)$. The increase of the SW level caused the prevalence of downwelling areas at the SWI $\left(\Delta T / \Delta t\right.$ shift from $0-1{ }^{\circ} \mathrm{C} / \mathrm{h}$ before to $1.5-3.5^{\circ} \mathrm{C} / \mathrm{h}$ during the flood). Only areas corresponding to $\mathrm{GW}$ discharge (GW3/GW4) identified in section 3.2 do not experience $\Delta T / \Delta t>1.5^{\circ} \mathrm{C} / \mathrm{h}$.

The second flood ( 2 Jul 2017, Figure $4 c \&$ d) is the smallest in terms of water level rise $(2.5 \mathrm{~cm})$ and $\mathrm{SW}$ temperature increase $\left(0.3{ }^{\circ} \mathrm{C}\right)$. Downwelling is less widespread compared to $25 \mathrm{Jul} 2016$, despite $\Delta T / \Delta t_{95 \%}$ being lower $\left(0.8^{\circ} \mathrm{C} / \mathrm{h}\right)$. However, both the second and the third flood, enabled a clear spatial identification of down-/upwelling areas (Figure 4df), showing that the $\Delta T / \Delta t_{95 \%}$-approach can be successfully applied even for small flood events with low overall temperature and water level increase.

Although all three floods are small $(=<5 \mathrm{~cm})$ their different intensities result in different sizes of downwelling areas. This reveals that care is required when interpreting the data. Areas identified as downwelling might only be downwelling during the flood event because of the altered hydraulic gradients due to the flood. Thus, the down-/upwelling distribution portrayed during floods may differ from the one during baseflow conditions. Instead, a sudden modification of the SW temperature without altering the flow would be useful to delineate downwelling areas during baseflow.

It turned out that the sequence of down-/upwelling areas identified with the $\Delta T / \Delta t_{95 \%}$ threshold resembles the streambed morphology of the study site, except for areas GW3/GW4 where GW upwelling withstands the flood perturbation. Riffle-pool sequences $(\mathrm{R}$ and $\mathrm{P}$ labels in Figure 4b, d, f) such as the one upstream of the log and transect TR4 reveals the agreement between $\Delta T / \Delta t$ and streambed morphology. In detail, this riffle area upstream of the log before transect TR4 shows high $\Delta T / \Delta t$ indicative of downwelling while downstream, where the $\Delta T / \Delta t$ values remain primarily below the threshold, pools prevail. Other high values of $\Delta T / \Delta t$ occur in areas of quick streamflow (QS label in Figures $4 \mathrm{~b}, \mathrm{~d}, \mathrm{f}$ ) over irregular bedforms such as upstream of transect TR1 and in the bend of the stream between transects TR2 and TR3 can be related to increased downwelling in areas of high streamflow speed (Packman \& Salehin, 2003; Wu et al., 2018). This approach of combining morphological and unsteady thermal information has potential to provide further insights into thermal exchange in bedforms under varying flow conditions. High precision surveys of the streambed would be an advantage for this purpose (e.g. laser scanning). 
3.3. Combined interpretation of FO-DTS, EMI and direct subsurface exploration to identify subsurface structures.

The inversion of EMI geophysics data provides electrical conductivity (EC) values of the streambed as an indicator of texture changes in the sediment under the prerequisite that the variability of the EC of the pore water can be neglected. The $0.75 \%$ and $2.5 \%$ misfit statistics values obtained for profiles A-A' and D-D' with the L2 norm method (Figure $5 \mathrm{a}_{1}$ and $\mathrm{a}_{2}$ ) are close to the ideal values of misfit of around $1 \%$. Figure $5 \mathrm{a} \& 5 \mathrm{~b}$ displays the inverted values of EC obtained from the EMI survey in a range from 5 to $23 \mathrm{mS} / \mathrm{m}$. The electrical conductivity values obtained from 72 pore water samples collected from the multi-level piezometers (at depths $-0.01,-0.14,-0.18,-0.23,-0.31,-0.48,-0.65,-0.82 \mathrm{~m}$ ) show a range of EC between 21 and $45 \mathrm{mS} / \mathrm{m}$. Locations showing a larger range of EC values in the vertical profile of the pore water samples (such as TR1L) show consistently a similar range width in the EMI values. Even though the EC range is similar between techniques, the offset between both methods suggests uncertain accuracy of the universal calibration of the EMI device for the specific subsurface characteristics of the streambed of River Schlaube. The correlation between the fluid conductivity and the bulk conductivity of the soil obtained with geophysics is weak, $\mathrm{R}^{2}=0.152$, and smaller than the $\mathrm{R}^{2}=0.34$ reported in Brosten et al. (2010). Such small correlation indicates the negligible effect of fluid conductivity changes on the distribution of electrical conductivities observed with geophysics. Thus, the EC values and their spatial changes observed with EMI are indicative of texture heterogeneity.

An abrupt transition in downstream direction of the longitudinal EC profiles can be observed from high EC values (in red) at transect TR1 to the low values at TR3/TR4 (in blue). Such discontinuities exist also with depth at TR1 and TR2 indicating stratification of materials. Low EC values prevail along transects TR3/TR4 with TR3 showing a region of slightly higher EC with vertical continuity (denoted in light blue) embedded in low EC materials (in dark blue). The high EC values at the left side of TR1 (Figure 5a $\mathrm{a}_{1} \& \mathrm{a}_{2}$ ) suggest the presence of either a conductive region or materials causing electric effects such as clay.

The diel-driven $A_{T}$ observed at TR1 at the SWI (upper face of Figure 5b1\& b2) show no permanent patterns attributable to $\mathrm{GW}$ discharge but to radiation, which suggests the existence of a layer blocking the flow. Additional evidence about the resistive nature of the high EC materials found in TR1 is provided from the vertical exploration of the sediment with the Pürckhauer corer (Figure 5c and Table 1). At both TR1 and TR2, fine clay and organic materials were retrieved in deep layers, stuck into the narrow section of the corer. The presence of clays below permeable sands and gravels agrees with the abrupt vertical transition from low to high EC values observed in the EMI profiles at around $1 \mathrm{~m}$ depth. The assimilation of high EC values to fine materials (in the absence of bedrock) is consistent with EMI geophysics observations of Rosenberry et al. (2016). Downstream, cores at TR3 and TR4 indicate the absence of fine-textured materials such as clay or organic deposits. As sands tend to be washed out from the corer in the overlying stream while retrieving the corer, the lost sediment of TR3 and TR4 can be considered as permeable material. This vertical continuity of permeable sediment of TR 3 and TR 4 corresponds well to the homogeneity of EC values displayed in the EMI profiles and to the presence of $A_{T}$ at the SWI observed by FO-DTS (upper face of Figure 5b of TR3 and TR4).

The combined interpretation of FO-DTS, EMI and direct sediment exploration enables reliable testing of consistencies between methods. The FO-DTS-based identification of areas GW3 and GW4 as permanent temperature anomalies is indicative of GW discharge. These findings correspond well with the sandy materials retrieved from cores along transects TR3 and TR4 where also EMI profiles indicate homogenous conditions of the aquifer at 
meter to decimeter scales. The vertical continuity of low values of EC at TR3 and TR4 representing coarse materials supports the identification of areas of GW discharge GW3 and GW4 at those transects. The agreement underlines the reliability of FO-DTS for the identification of groundwater exchange based on temperature patterns.

The absence of significant temperature anomalies attributable to groundwater or interflow discharge at transect TR1 is in correspondence with the high EC region identified in the first half of the EMI profiles as the fine materials of low hydraulic conductivity extracted from the lower layers of the soil cores. In view of the successful identification of the two distinct areas of clogged materials at TR1 and TR2 and conductive ones at TR3 and TR4, EMI also succeeded in revealing the meter to decameter scale of spatial heterogeneity of the aquifer. These findings are consistent with the reported impacts of intermediate-scale aquifer heterogeneity on groundwater seepage (Fleckenstein, Niswonger, \& Fogg, 2006).

However, due to the spatial averaging of the electromagnetics induced by such a wide EMI device (almost $4 \mathrm{~m}$ wide), the EC values obtained are limited in resolution (Binley et al., 2015). We are aware that the small scale heterogeneity of the subsurface, in particular at the upper layers caused by scour and deposition, remains undetected. Given the strong impact of this small heterogeneity in the sub-meter water exchange of the HZ (Krause et al., 2012), detailed subsurface exploration is recommended.

EMI surveys or other geophysical techniques with decimeter or even centimeter resolution of shallow subsurface are also necessary to support our findings of FO-DTS about local SW downwelling during floods. Similarly, high-resolution topographic monitoring of bedforms as described in Brasington, Vericat, \& Rychkov (2012) could help to distinguish the particular impacts of the thermal, morphological and sedimentary controls on the local hyporheic exchange.

In the present study, EMI has only been applied to study subsurface structure underneath the stream. However, the method could also be applied to study subsurface structures alongside the stream. Time series of EMI investigations at the slopes of the Schlaube valley might be useful to investigate interflow since a changing water saturation of the soil can be easily identified with EMI time series (Robinson et al., 2008).

\section{Conclusions}

A high-density mesh of FO-DTS installed at the sediment-water interface shows capabilities for the differentiation of groundwater and interflow components based on spatial and temporal analysis of the temperature patterns. The high spatial and temporal resolution of FO-DTS allows observing the alteration of the exchange during transient states such as rain events and floods. In particular, transient conditions enable (1) the identification of interflow based on the temporal evolution of the temperature anomalies and (2) local surface-water downwelling based on their low resilience to temperature and pressure changes in the overlying water. However, the technique has limited capability to infer the factors causing the observed spatial heterogeneity of the temperature patterns. Aiming to overcome this limitation of FO-DTS and prove the source of the groundwater component, geophysical techniques, such as electromagnetic induction (EMI), can provide in-depth exploration of the sediment. The electrical conductivity profiles and maps provided by the EMI technique can qualitatively infer texture changes in the sediment. This capability is particularly useful to identify streambed structures relevant for connectivity/disconnectivity of groundwater and surface water, which enables to check the validity of the identification of the areas of water exchange distinguished with FO-DTS. We encourage the hyporheic community to address 
the challenging steps ahead to extend FO-DTS capabilities as well as to foster the combined use and evaluation of the different techniques to improve our understanding of GW-SW exchange across scales.

\section{References}

Anderson, M. P. (2005). Heat as a groundwater tracer. Groundwater, 43(6), 951-968. doi: 10.1111/j.1745-6584.2005.00052.x

Bencala, K. E. (2005). 113: Hyporheic exchange flows. Encyclopedia of Hydrological Sciences, 1-7.

Binley, A., Ullah, S., Heathwaite, A. L., Heppell, C., Byrne, P., Lansdown, K., .. \& Z Zhang, H. (2013). Revealing the spatial variability of water fluxes at the groundwater-surface water interface. Water Resources Research, 49(7), 3978-3992. doi: 10.1002/wrcr.20214

Binley, A., Hubbard, S. S., Huisman, J. A., Revil, A., Robinson, D. A., Singha, K., \& Slater, L. D. (2015). The emergence of hydrogeophysics for improved understanding of subsurface processes over multiple scales. Water resources research, 51(6), 3837-3866. doi.org/10.1002/2015WR017016

Blume, T., Krause, S., Meinikmann, K., \& Lewandowski, J. (2013). Upscaling lacustrine groundwater discharge rates by fibre-optic distributed temperature sensing. Water Resources Research, 49(12), 7929-7944. doi: 10.1002/2012WR013215

Boaga, J. (2017). The use of FDEM in hydrogeophysics. Journal of Applied Geophysics, 139, 36-46. doi: 10.1016/j.jappgeo.2017.02.011

Brasington, J., Vericat, D., \& Rychkov, I. (2012). Modelling river bed morphology, roughness, and surface sedimentology using high-resolution terrestrial laser scanning. Water Resources Research, 48(11). doi: 10.1029/2012WR012223

Briggs, M. A., Lautz, L. K., \& McKenzie, J. M. (2012a). A comparison of fibre-optic distributed temperature sensing to traditional methods of evaluating groundwater inflow to streams. Hydrological Processes, 26(9), 1277-1290. doi: 10.1002/hyp.8200

Briggs, M. A., Lautz, L. K., McKenzie, J. M., Gordon, R. P. \& Hare, D. K. (2012b). Using high-resolution distributed temperature sensing to quantify spatial and temporal variability in vertical hyporheic flux. Water Resources Research, 48(2). doi: 10.1029/2011WR011227

Brosten, T. R., Day-Lewis, F. D., Schultz, G. M., Curtis, G. P., \& Lane Jr, J. W. (2011). Inversion of multi-frequency electromagnetic induction data for 3D characterization of hydraulic conductivity. Journal of Applied Geophysics, 73(4), 323-335. doi:

10.1016/j.jappgeo.2011.02.004

Cardenas, M. B., \& Wilson, J. L. (2007). Thermal regime of dune-covered sediments under gaining and losing water bodies. Journal of Geophysical Research: Biogeosciences, 112(G4). doi: 10.1029/2007JG000485

Constantz, J., \& Stonestrom, D. A. (2003). Heat as a tracer of water movement near streams. US Geological Survey Circular, (1260), 1-96. 
Crook, N., Binley, A., Knight, R., Robinson, D. A., Zarnetske, J., \& Haggerty, R. (2008). Electrical resistivity imaging of the architecture of substream sediments. Water Resources Research, 44(4). doi: 10.1029/2008WR006968

Dakin, J. (1987). Multiplexed and distributed optical fibre sensor systems. Journal of Physics E: Scientific Instruments, 20(8), 954. doi: 10.1088/0022-3735/20/8/002

Day-Lewis, F. D., White, E. A., Johnson, C. D., Lane Jr, J. W., \& Belaval, M. (2006).

Continuous resistivity profiling to delineate submarine groundwater discharge: Examples and limitations. The Leading Edge, 25(6), 724-728. doi: 10.1190/1.2210056

Fleckenstein, J. H., Niswonger, R. G., \& Fogg, G. E. (2006). River-aquifer interactions, geologic heterogeneity, and low-flow management. Groundwater, 44(6), 837-852.

González-Pinzón, R., Ward, A. S., Hatch, C. E., Wlostowski, A. N., Singha, K., \& Brock, J. T. (2015). A field comparison of multiple techniques to quantify groundwater-surface-water interactions. Freshwater Science, 34(1), 139-160. doi: 10.1086/679738.

Gourry, J. C., Vermeersch, F., Garcin, M. \& Giot, D. (2003). Contribution of geophysics to the study of alluvial deposits: a case study in the Val d'Avaray area of the River Loire, France". Journal of applied geophysics, 54, 35-49. doi: 10.1016/j.jappgeo.2003.07.002

Hare, D. K., Briggs, M. A., Rosenberry, D. O., Boutt, D. F., \& Lane, J. W. (2015). A comparison of thermal infrared to the fibre-optic distributed temperature sensing for evaluation of groundwater discharge to surface water. Journal of Hydrology, 530, 153-166. doi: 10.1016/j.jhydrol.2015.09.059.

Hare, D. K., Boutt, D. F., Clement, W. P., Hatch, C. E., Davenport, G. (2017).

Hydrogeological controls on spatial patterns of groundwater discharge in peatlands.

Hydrology and Earth System Sciences, 21(12) 6031-6048. doi: 10.5194/hess-21-6031-2017.

Henderson, R. D., Day-Lewis, F. D., \& Harvey, C. F. (2009). Investigation of aquifer-estuary interaction using wavelet analysis of fibre-optic temperature data. Geophysical Research Letters, 36(6). doi: 10.1029/2008GL036926.

Kasahara, T., \& Hill, A. R. (2007). Lateral hyporheic zone chemistry in an artificially constructed gravel bar and a re-meandered stream channel, Southern Ontario,

Canada. Journal of the American Water Resources Association, 43(5), 1257-1269. doi: 10.1111/j.1752-1688.2007.00108.x

Kendall, M., Stuart, A., \& Ord, J. K. (1983). The advanced theory of statistics, Vol.3, pp. 410-414.

Krause, S., Blume, T., \& Cassidy, N. (2012). Investigating patterns and controls of groundwater up-welling in a lowland river by combining Fibre-optic Distributed Temperature Sensing with observations of vertical hydraulic gradients. Hydrology and Earth System Sciences, 16(6), 1775-1792. doi: 10.5194/hess-16-1775-2012.

Lesch, S. M., Corwin, D. L., \& Robinson, D. A. (2005). Apparent soil electrical conductivity mapping as an agricultural management tool in arid zone soils. Computers and Electronics in Agriculture, 46(1-3), 351-378. doi: 10.1016/j.compag.2004.11.007

Lewandowski, J., Angermann, L., Nützmann, G., \& Fleckenstein, J. H. (2011). A heat pulse technique for the determination of small-scale flow directions and flow velocities in the streambed of sand-bed streams. Hydrological Processes, 25(20), 3244-3255.

doi: 10.1002/hyp.8062. 
Loke, M. H., Acworth, I., \& Dahlin, T. (2003). A comparison of smooth and blocky inversion methods in 2D electrical imaging surveys. Exploration Geophysics, 34(3), 182-187. doi: 10.1071/EG03182.

Lowry, C. S., Walker, J. F., Hunt, R. J., \& Anderson, M. P. (2007). Identifying spatial variability of groundwater discharge in a wetland stream using a distributed temperature sensor. Water Resources Research, 43(10). doi: 10.1029/2007WR006145.

Mansoor, N., Slater, L., Artigas, F., \& Auken, E. (2006). High-resolution geophysical characterization of shallow-water wetlands. Geophysics, 71(4), B101-B109. doi: $10.1190 / 1.2210307$

Mwakanyamale, K., Slater, L., Day-Lewis, F.D., Elwaseif, M., \& Johnson, C. (2012). Spatially variable stage-driven groundwater-surface water interaction inferred from time-frequency analysis of distributed temperature sensing data. Geophysical Research Letters, 39(6). doi: 10.1029/2011GL050824

Packman, A. I., \& Salehin, M. (2003). Relative roles of stream flow and sedimentary conditions in controlling hyporheic exchange. Hydrobiologia, 494(1-3), 291-297. doi: 10.1023/A:102540342

Robinson, D. A., Binley, A., Crook, N., Day-Lewis, F. D., Ferré, T. P. A., Grauch, V. J. S., ... \& Nyquist, J. (2008). Advancing process-based watershed hydrological research using near-surface geophysics: A vision for, and review of, electrical and magnetic geophysical methods. Hydrological Processes, 22(18), 3604-3635. doi: 10.1002/hyp.6963

Robinson, D. A., Lebron, I., Kocar, B., Phan, K., Sampson, M., Crook, N. \& Fendorf, S. (2009). Time-lapse geophysical imaging of soil moisture dynamics in tropical deltaic soils: An aid to interpreting hydrological and geochemical processes, Water Resources Research, 45, doi:10.1029/2008WR006984.

Rosenberry, D.O., Briggs, M.A., Voytek, E.B., \& Lane, J.W. (2016). Influence of groundwater on distribution of dwarf wedgemussels (Alasmidonta heterodon) in the upper reaches of the Delaware River, northeastern USA. Hydrology and Earth System Sciences 20(10): 4323-4339 doi: 10.5194/hess-20-4323-2016.

Selker, J. S., Thévenaz, L., Huwald, H., Mallet, A., Luxemburg, W., Van De Giesen, N., ... \& Parlange, M. B. (2006a). Distributed fiber-optic temperature sensing for hydrologic systems. Water Resources Research, 42(12). doi: 10.1029/2006WR005326.

Selker, J. S., Van de Giesen, N., Westhoff, M., Luxemburg, W., \& Parlange, M. B. (2006b). Fiber optics opens a window on stream dynamics. Geophysical Research Letters, 33(24). doi: 10.1029/2006GL027979.

Shanafield, M., Mccallum, J.L., Cook, P. G. \& Noorduijn, S. (2016). Variations on thermal transport modelling of subsurface temperatures using high-resolution data. Advances in Water Resources, 89. doi: 10.1016/j.advwatres.2015.12.018.

Slater, L., \& Lesmes, D. P. (2002). Electrical-hydraulic relationships observed for unconsolidated sediments. Water Resources Research, 38(10), 31-1. doi: 10.1029/2001WR001075.

Slater, L. D., Ntarlagiannis, D., Day-Lewis, F. D., Mwakanyamale, K., Versteeg, R. J., Ward, A., ... \& Lane, J. W. (2010). Use of electrical imaging and distributed temperature sensing methods to characterize surface water-groundwater exchange regulating uranium transport at the Hanford 300 Area, Washington. Water Resources Research, 46(10). doi: 10.1029/2010WR009110. 
Tyler, S. W., Selker, J. S., Hausner, M. B., Hatch, C. E., Torgersen, T., Thodal, C. E., \& Schladow, S. G. (2009). Environmental temperature sensing using Raman spectra DTS fiber-optic methods. Water Resources Research, 45(4). doi: 10.1029/2008WR007052.

Villeneuve, S., Cook, P. G., Shanafield, M., Wood, C., \& White, N. (2015). Groundwater recharge via infiltration through an ephemeral riverbed, central Australia. Journal of Arid Environments, 117, 47-58. doi: 10.1016/j.jaridenv.2015.02.009

Vogt, T., Schneider, P., Hahn-Woernle, L., \& Cirpka, O. A. (2010). Estimation of seepage rates in a losing stream by means of fiber-optic high-resolution vertical temperature profiling. Journal of Hydrology, 380(1-2), 154-164. doi: 10.1016/j.jhydrol.2009.10.033

Lyon, J. G., Trimble, S. W. \& Ward, A. D. (2004). Environmental hydrology. CRC Press.

Watson, J. A., Cardenas, M. B., Ferencz, S. B., Knappett, P. S., \& Neilson, B. T. (2018). The effects of floods on the temperature of riparian groundwater. Hydrological Processes. doi: 10.1002/hyp.11504

Westhoff, M. C., Savenije, H. H. G., Luxemburg, W. J., Stelling, G. S., Van de Giesen, N. C., Selker, J. S., ... \& Uhlenbrook, S. (2007). A distributed stream temperature model using highresolution temperature observations. Hydrology and Earth System Sciences

Discussions, 11(4), 1469-1480. doi: 10.5194/hess-11-1469-2007

Winter, T.C. (1998). Groundwater and surface water: A single resource. USGS Circular 1139.

Wu, L., Singh, T., Gomez-Velez, J., Nützmann, G., Wörman, A., Krause, S., \& Lewandowski, J. (2018). Impact of Dynamically Changing Discharge on Hyporheic Exchange Processes under Gaining and Losing Groundwater Conditions. Water Resources Research, doi: 10.1029/2018WR023185.

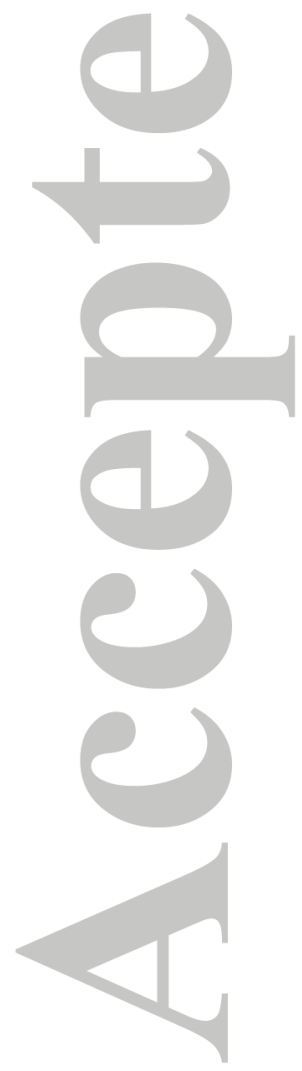




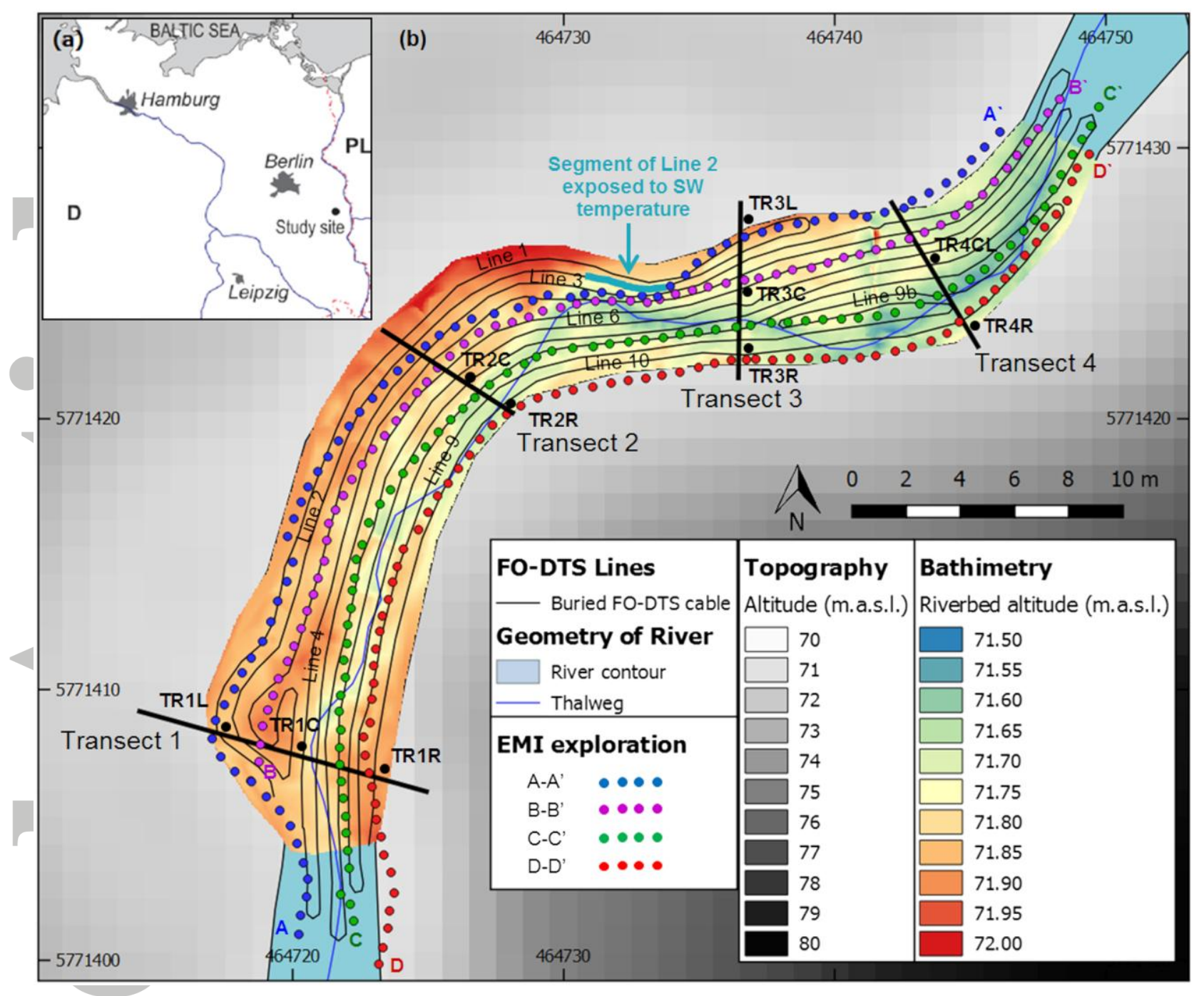

Figure 1. Study site. (a) Location of the study site in northeast Germany. (b) Detailed elevation map including bathymetry of the River Schlaube, layout of FO-DTS cable and lines of EMI measurements. Transects are locations of additional measurements as described in Table 1. TRij location (e.g. TR4C) defines transect $\mathrm{i}$ at its transversal position $\mathrm{j}$ in the direction of flow (L: left, C: center, CL: center-left, R: right). 


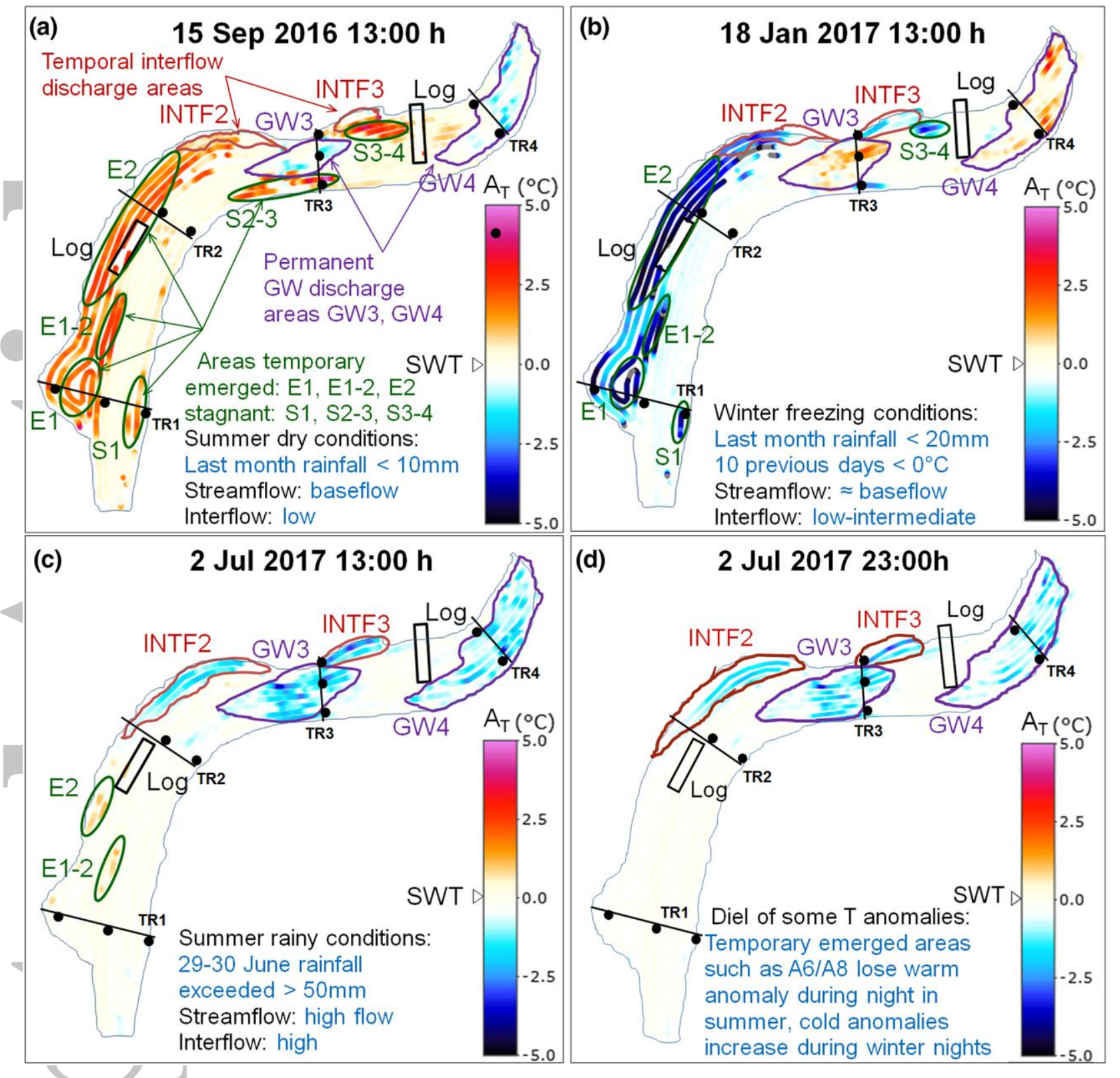

Figure 2. $(\mathrm{a}, \mathrm{b}, \mathrm{c})$ Maps of temperature anomalies AT $\left({ }^{\circ} \mathrm{C}\right)$ at the SWI (deviation of the SWI temperature from the SW temperature) under (a) dry summer conditions with low river stage and strong radiation, (b) winter conditions with ice formation in stagnant areas, (c) summer wet conditions with interflow discharge after rainfalls, and (d) the temporal disappearance of the temperature anomalies of temporary emerged areas (E1, E1-2, E2) due to the absence of radiation during night. 
(a)

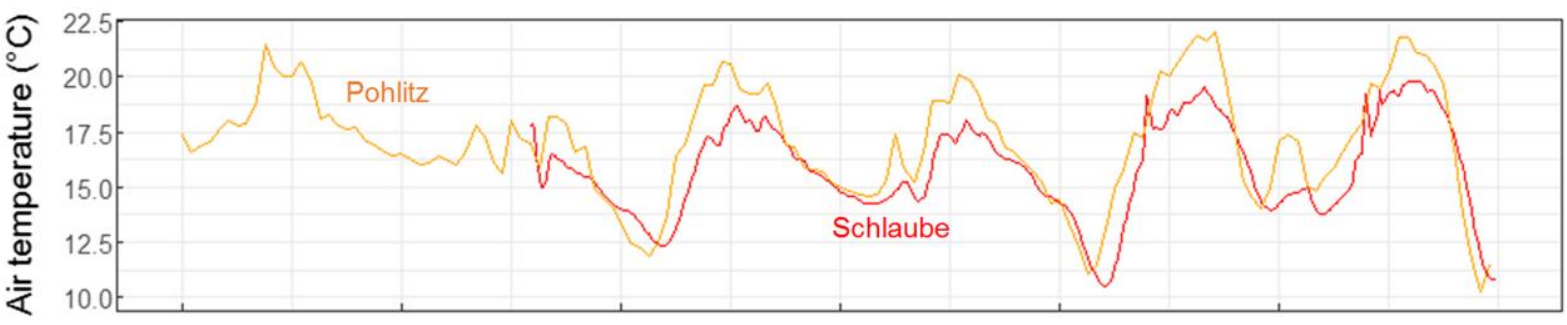

(b)

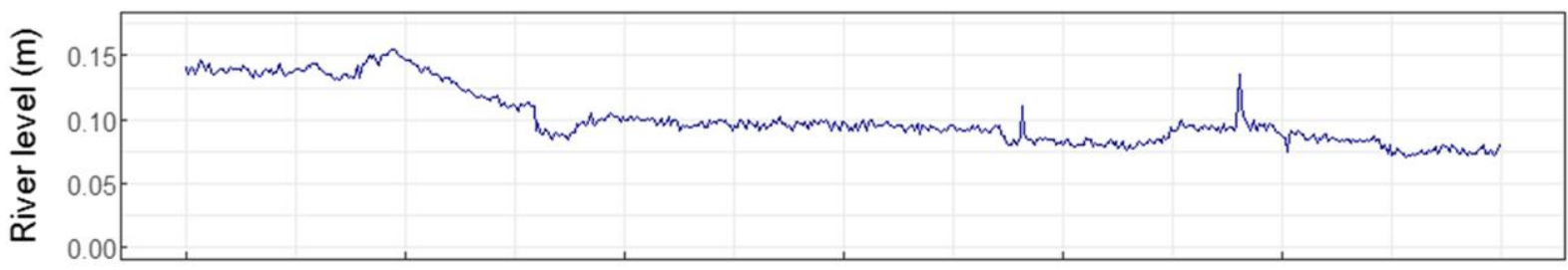

(c)

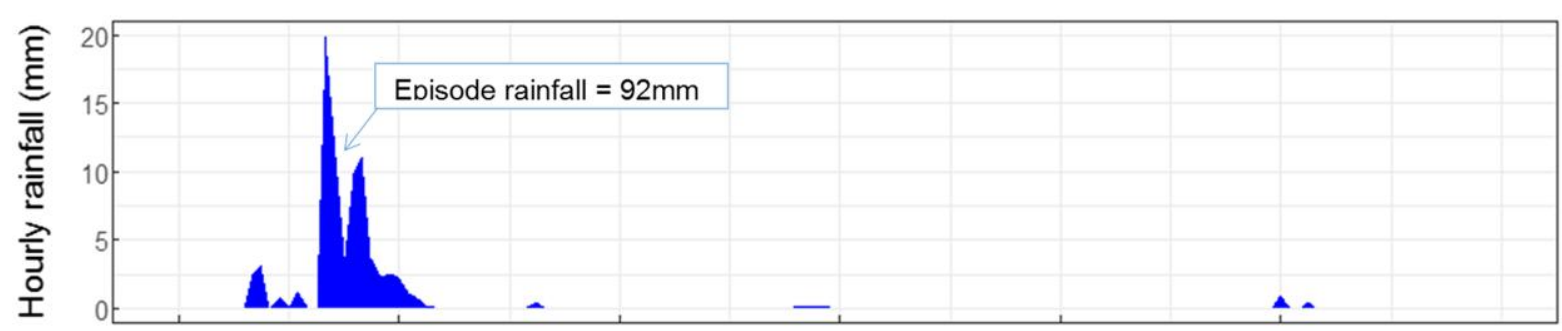

(d)

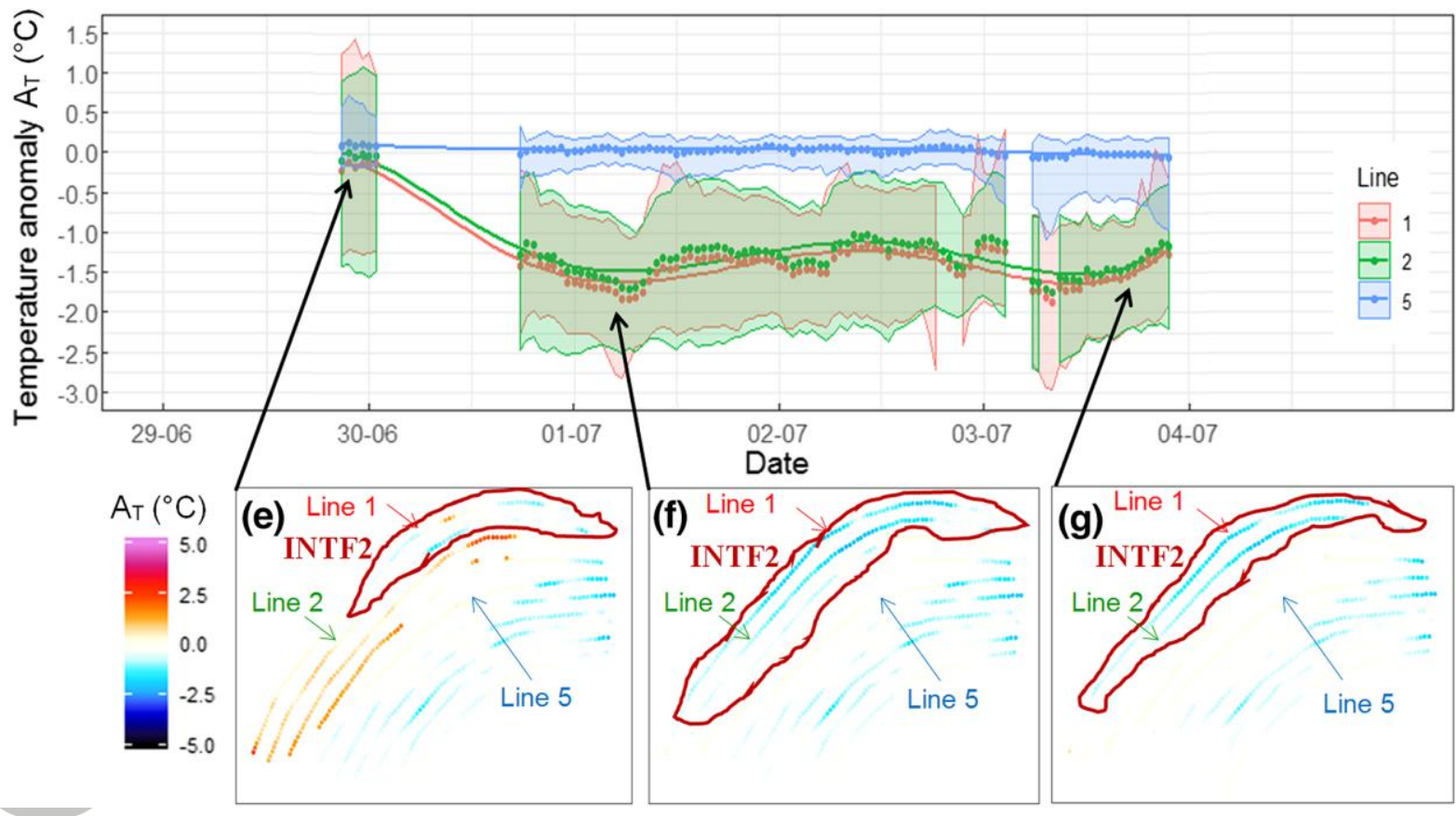

Figure 3: Time series of environmental conditions and interflow during and after the intense rainfall episode at 29 Jun 2017. (a) Air temperatures at Schlaube (red line) and the closest (8 km) German Meteorological Service (DWD) station 3967 at Pohlitz (orange line) show increasing daily temperature amplitudes after the end of the rainfall episode. (b) The streamflow barely responds to the intense rainfall episode. Overall, there is a trend of a temporarily decreasing river stage. (c) Hourly rainfall measured by DWD in Pohlitz. Other stations farther from the study site show consistently heavy regional rainfalls. (d) Time series of spatially averaged temperature anomalies AT of the FO-DTS fiber for the sections in area 
INTF2 of Lines 1, 2 and 5 (panels e-g). Note that the delineation of area INTF2 is temporally changing and thus the number of averaged values of the temperature anomalies is also varying. Shaded areas are $95 \%$ confidence intervals of the mean temperature anomaly of the points from each line included in region INTF2 on each time step. Surface water and groundwater discharge prevail outside of area INTF2, which explains the quasi-constant temperature anomaly of the approximately 30 points of Line 5 parallel to INTF2. Conversely, DTS lines 1 and 2 located close to the left shoreline (e-g) reveal a sharp temperature decrease in the first day after the rainfall episode and recover steadily afterwards; a phenomenon that is consistent with the temporal evolution of interflow discharge. (e-g) Section of study site with area INTF2 visualizing the spatial pattern of the temperature anomalies and their temporal evolution. The change of INTF2 occurs preferably along the margin, consistent with the origin of interflow.

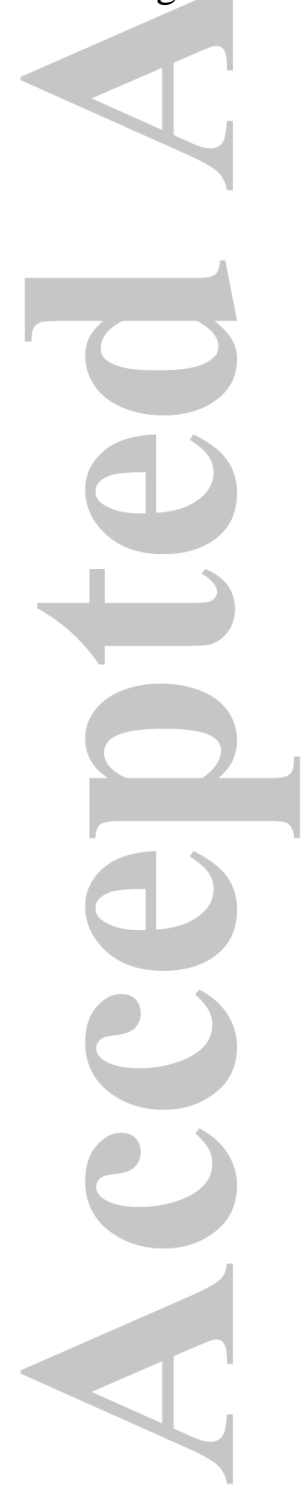




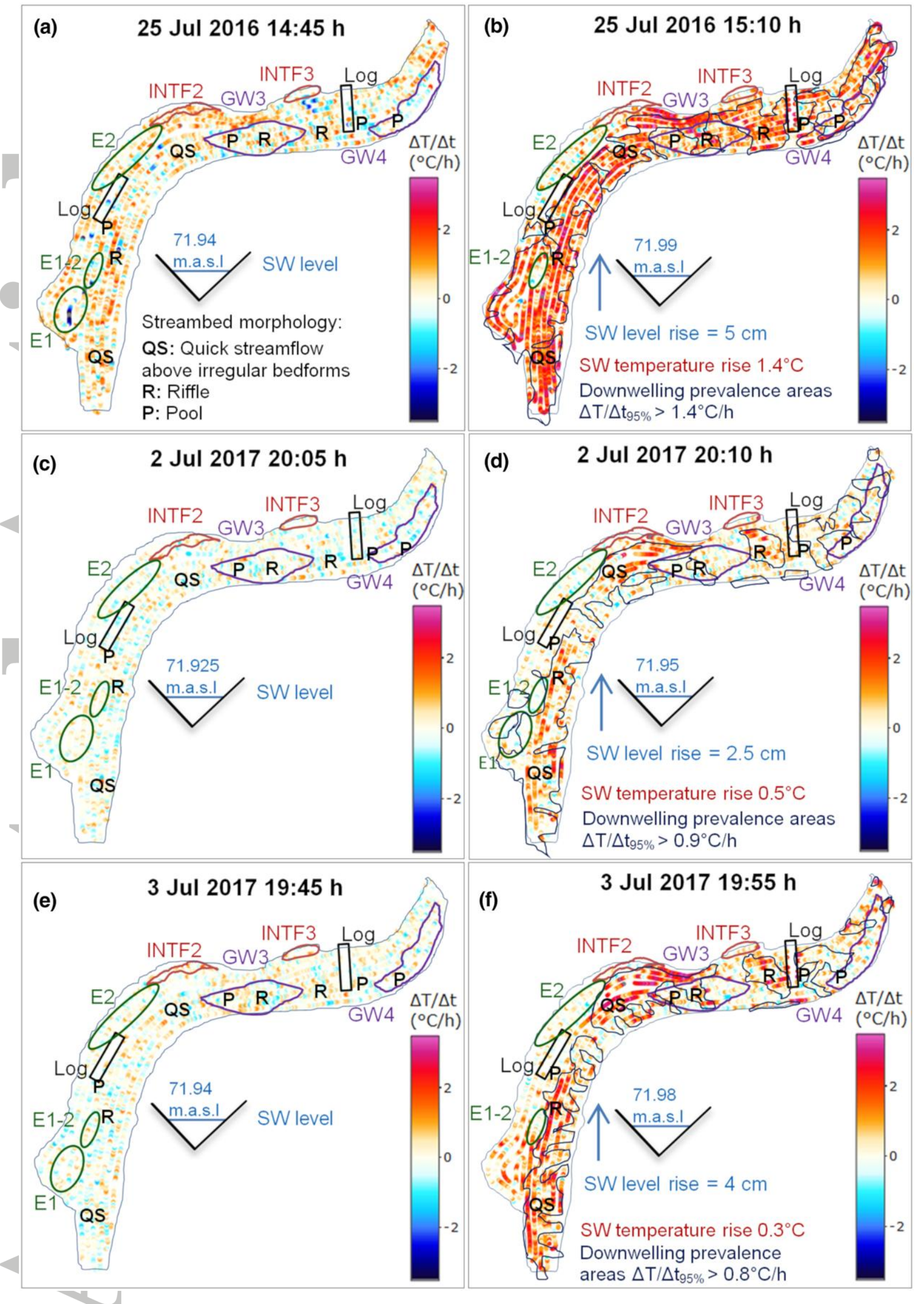

Figure 4: Rates of temperature change $\Delta \mathrm{T} / \Delta \mathrm{t}\left({ }^{\circ} \mathrm{C} / \mathrm{h}\right)$ under no-flood $(\mathrm{a}, \mathrm{c}, \mathrm{e})$ and flood $(\mathrm{b}, \mathrm{d}, \mathrm{f})$ conditions for three events recorded with FO-DTS: (a, b) 25 Jul 2016, (c, d) 2 Jul 2017, (e, f) 
3 Jul 2017. Warming rates previous to flood transit are higher in the case of $25 \mathrm{Jul} 2016$ compared to the other two dates due to high radiation (up to $1{ }^{\circ} \mathrm{C} / \mathrm{h}$ ) at midday, but much lower than flood warming rates (up to $3.5^{\circ} \mathrm{C} / \mathrm{h}$ ). Areas, where downwelling prevails, are delineated in (b, d, f) with dark blue lines based on the calculated thresholds of $\Delta T / \Delta t 95 \%$. The most relevant morphological features of the streambed are labelled with QS (quick streamflow above irregular bedforms), R (riffles) and P (pools).

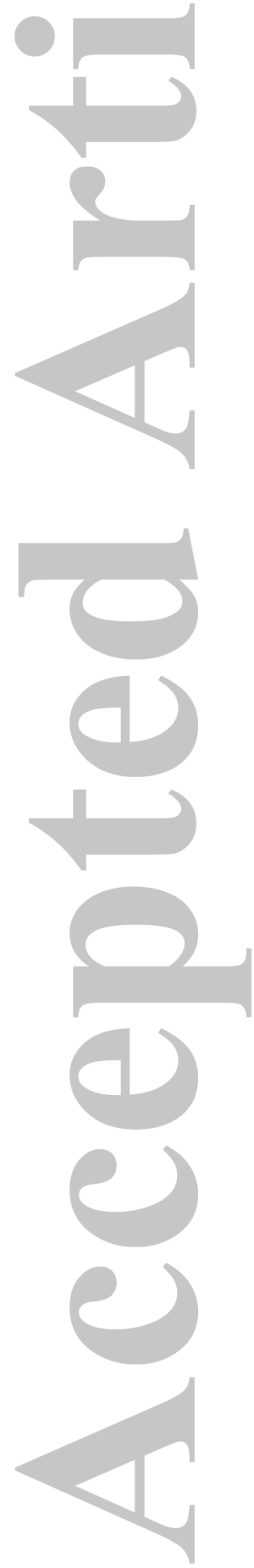



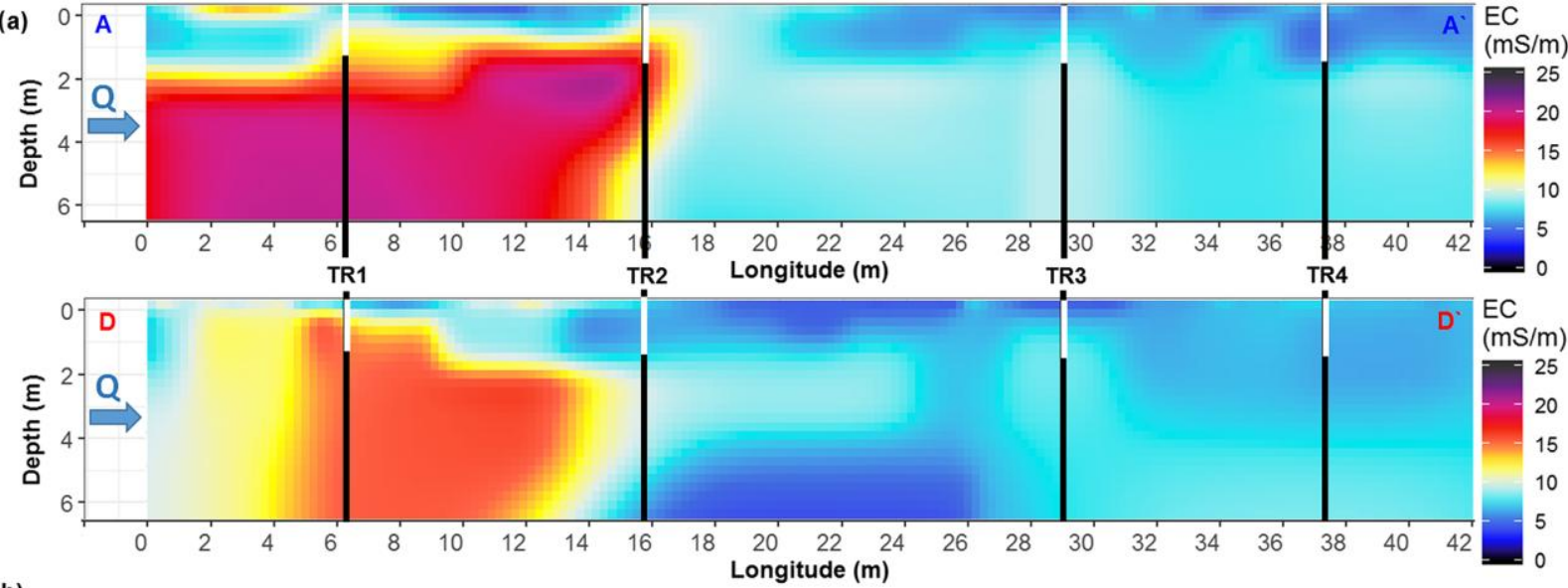

(b)

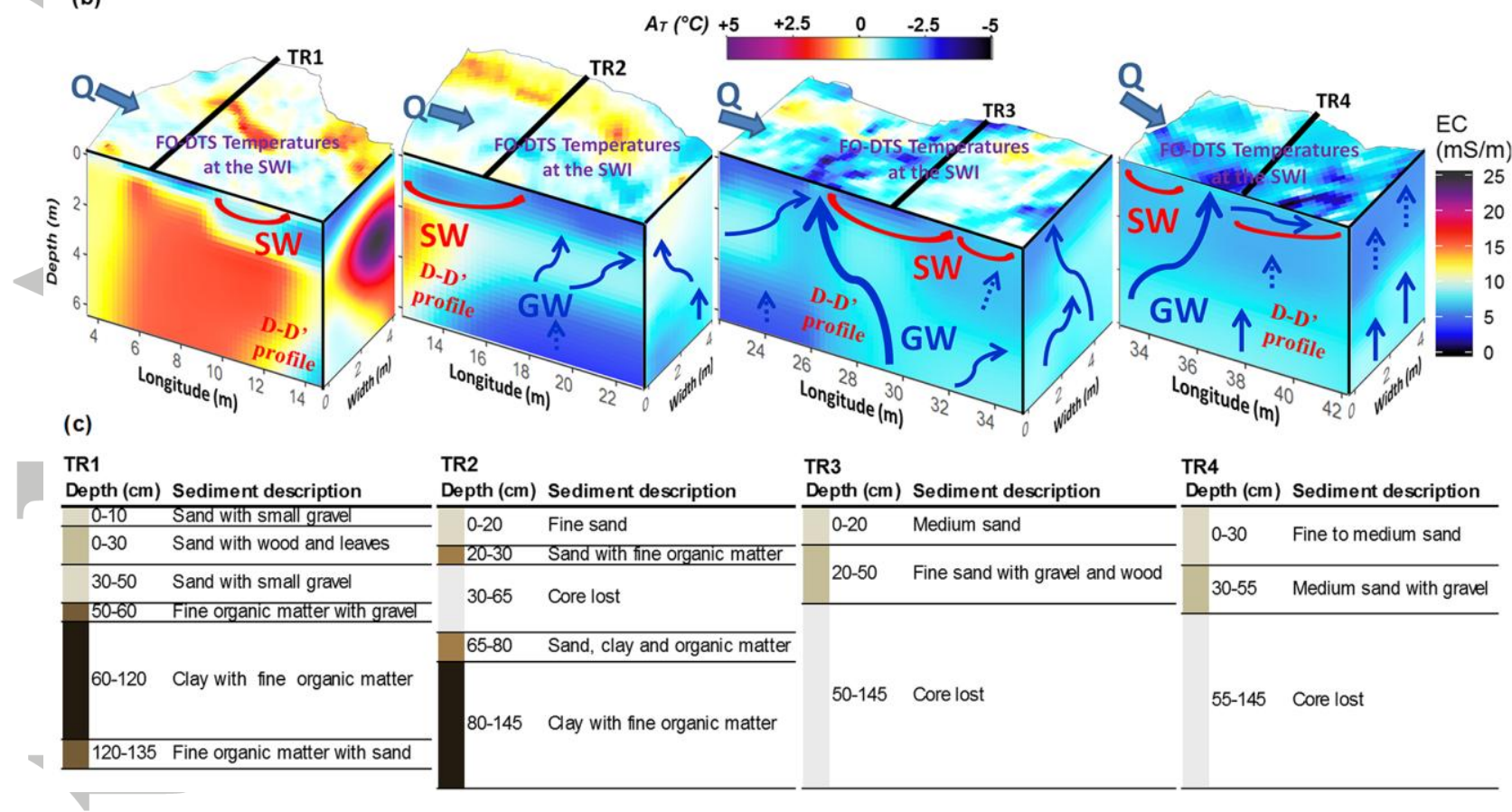

Figure 5: (a) Longitudinal profiles $A-A^{`}$ and $D-D^{`}$ (compare Figure 1b) of electrical conductivity $(\mathrm{mS} / \mathrm{m}$ ) down to approximately $6 \mathrm{~m}$ depth obtained from the 2D inversion of EMI geophysics data along approx. $50 \mathrm{~m}$ of the study site. (b) Prismatic models of the riverbed at transects TR1, TR2, TR3 and TR4 representing FO-DTS temperature anomalies at the SWI in the upper face of the prisma (horizontal) and electrical conductivity profiles in the lateral faces of the prisma (vertical). The blue and red arrows conceptualize the paths of groundwater (GW) and surface water (SW) flows based on both, subsurface structures detected in the EMI survey and temperature anomalies observed at the SWI by FO-DTS. The $\mathrm{Q}$ arrow represents the direction of streamflow and indicates the location of the Thalweg. (c) Subsurface stratification and sediment types based on cores collected at transects TR1-TR4 with a Pürckhauer corer (Table 1). Location and length of cores is indicated in (a) panels as white lines. Lost segments of cores correspond to medium to coarse permeable sands that were washed out of the corer in the overlying stream during retrieving the corer. 
Table 1. Technical specifications of the instruments and measurement setups.

\begin{tabular}{|c|c|c|c|c|}
\hline Parameter & Device & & Details & $\begin{array}{l}\text { Date (hours measured } \\
\text { / N number of time steps) }\end{array}$ \\
\hline $\begin{array}{l}\text { SWI } \\
\text { temper }\end{array}$ & $\begin{array}{l}\text { FO-DTS: Silixa Ultima } \\
\text { control unit } \\
\text { ( } 4 \text { km range, } 2 \text { channels) } \\
590 \text { m Brugg BRUsens } \\
\text { armoured fibre optic cable } \\
(2 \times \text { MMF metallic } 4.6 \\
\text { mm, } 25 / 125 \mathrm{~nm})\end{array}$ & $\begin{array}{l}10 \text { longitudinal } \\
\text { lines in } 50 \mathrm{~m} \text { long } \\
\text { stream section, } \\
\text { separated } 20-50 \\
\mathrm{~cm} \text {, buried } 3-8 \mathrm{~cm} \\
\text { in the streambed }\end{array}$ & $\begin{array}{l}\text { Sampling rate: } 4 \min (2016) \\
\qquad 5 \min (2017) \\
\text { Longitudinal resolution } \approx 0.3 \mathrm{~m}, \\
\text { (sample points every } 0.127 \mathrm{~m}) \\
\text { Temperature resolution } \approx 0.03{ }^{\circ} \mathrm{C} \\
\text { Time series of temperature } \\
\text { for } 3611 \text { points in the riverbed }\end{array}$ & $\begin{array}{l}\text { 25 Jul } 2016(4.5 \mathrm{~h} / \mathrm{N}=68) \\
\text { Flood event } 1 \\
\text { 15 Sep } 2016(7.5 \mathrm{~h} / \mathrm{N}=60) \\
\text { 18 Jan } 2017(4.5 \mathrm{~h} / \mathrm{N}=54) \\
\text { 2-3 Jul } 2017 \\
\text { (continuous: } 48 \mathrm{~h} / \mathrm{N}=576) \\
\text { Flood events } 2 \text { and } 3 \\
\text { (Within the quasi-continuous } \\
\text { period } 30 \text { Jun- } 4 \text { Jul 2017) }\end{array}$ \\
\hline $\begin{array}{l}\text { Piezometric } \\
\text { head }\end{array}$ & $\begin{array}{l}\text { Hand-made multi-level } \\
\text { piezometers }\end{array}$ & $\begin{array}{l}3 \text { in Transect 1, } \\
2 \text { in Transect 2, } \\
3 \text { in Transect 3, } \\
2 \text { in Transect } 4\end{array}$ & $\begin{array}{l}\text { Resolution: } 0.01 \mathrm{~cm} \mathrm{H}_{2} \mathrm{O}, \\
\text { Accuracy: } 0.5 \mathrm{~cm} \mathrm{H}_{2} \mathrm{O} \\
\text { Depth of filter screens: } \\
\text { (v2016: } 5 / 15 / 25 / 35 / 45 / 55 \mathrm{~cm} \text { deep) } \\
\text { (v2017: } 1 / 8 / 14 / 23 / 31 / 48 / 65 / 82 \mathrm{~cm} \text { ) }\end{array}$ & 1 Aug 2016 - 4 Jul 2017 \\
\hline $\begin{array}{l}\text { Air and water } \\
\text { temperature }\end{array}$ & 2 HOBO Tidbits v2 & Transect 1 & $\begin{array}{l}\text { Resolution: } 0.02{ }^{\circ} \mathrm{C} \text { at } 25^{\circ} \mathrm{C} \\
\text { Accuracy: } \pm 0.21{ }^{\circ} \mathrm{C} \text { from } 0-50{ }^{\circ} \mathrm{C}\end{array}$ & $\begin{array}{l}5 \text { Mar - } 30 \text { Aug } 2016 \\
\text { Sampling rate: } 15 \mathrm{~min}\end{array}$ \\
\hline $\begin{array}{l}\text { Streamflow } \\
\text { velocity }\end{array}$ & $\begin{array}{l}\text { Hydromet OTT-OTT } \\
\text { MF pro }\end{array}$ & $\begin{array}{l}\text { Transect } 1, \\
\text { Transect 3, } \\
\text { Transect } 4\end{array}$ & $\begin{array}{l}\text { Accuracy: } \\
\pm 2 \% \text { flow value } \\
\pm 0.015 \mathrm{~m} / \mathrm{s} \text { speed }(0-3 \mathrm{~m} / \mathrm{s})\end{array}$ & $\begin{array}{l}15 \text { Sep } 2016, \\
20 \text { Feb } 2017, \\
\text { 2-3 Jul } 2017\end{array}$ \\
\hline $\begin{array}{l}\text { Electrical } \\
\text { conductivity of } \\
\text { sediment }\end{array}$ & CMD-Explorer & $\begin{array}{l}4 \text { longitudinal lines } \\
\text { of } 45 \mathrm{~m} \text { length, } \\
\text { measurement } \\
\text { points separated } \\
0.6 \mathrm{~m} .\end{array}$ & $\begin{array}{l}\text { Sampling rate: } 10 \mathrm{~s} \\
\text { Effective depth of exploration: } \\
\text { (H) } 2.2-4.2-6.7 \mathrm{~m} /(\mathrm{L}) 1.1-2.1-3.3 \mathrm{~m} \\
\text { EC resolution }=0.1 \mathrm{mS} / \mathrm{m} \\
\text { EC accuracy }= \pm 4 \% \text { at } 50 \mathrm{mS} / \mathrm{m} \\
\text { Temperature stability }= \pm 0.1 \mathrm{mS} / \mathrm{m} /{ }^{\circ} \mathrm{C}\end{array}$ & $\begin{array}{l}4 \text { Jul } 2017 \\
17 \text { Oct } 2017\end{array}$ \\
\hline $\begin{array}{l}\text { Electrical } \\
\text { conductivity of } \\
\text { pore water }\end{array}$ & $\begin{array}{l}\text { Greissinger GMH3410 } \\
\text { conductivity meter }\end{array}$ & $\begin{array}{l}80 \text { samples in sets } \\
\text { of } 8 \text { from the } 10 \\
\text { multi-level } \\
\text { piezometers }\end{array}$ & $\begin{array}{l}\text { Range of conductivity: } 0-200 \mathrm{mS} / \mathrm{cm} \\
\text { Accuracy: (the larger value applies) } \\
\pm 0.5 \% \text { of reading } \\
\pm 0.3 \% \text { full scale } \\
\pm 2 \mathrm{mS} / \mathrm{cm}\end{array}$ & 4 Jul 2017 \\
\hline $\begin{array}{l}\text { Saturated } \\
\text { hydraulic } \\
\text { conductivity } \\
\mathrm{K}_{\mathrm{s}} \text {, Thermal } \\
\text { conductivity } \lambda \text {, } \\
\text { thermal } \\
\text { diffusivity } \kappa \text {, } \\
\text { volumetric } \\
\text { thermal } \\
\text { capacity } \mathrm{C}, \\
\text { thermal } \\
\text { resistivity } \rho \\
\text { and porosity } \\
\text { of sediment }\end{array}$ & $\begin{array}{l}\text { Co. UMS (now Co. } \\
\text { METER) K-SAT dynamic } \\
\text { head permeameter } \\
\& \\
\text { Co. Decagon (now Co. } \\
\text { METER) } \\
\text { K2PRO thermal probe }\end{array}$ & $\begin{array}{l}24 \text { sediment } \\
\text { samples of } 50 \mathrm{~cm} \\
\text { height were } \\
\text { collected in metal } \\
\text { Rings from the } \\
\text { upper } 5 \mathrm{~cm} \text { of the } \\
\text { streambed in } 0.5 \\
\text { and } 1 \text { m distance } \\
\text { downstream of } \\
\text { each transect }\end{array}$ & $\begin{array}{l}\text { KSAT: } \\
\text { Range of } \mathrm{K}_{\mathrm{s}}: 0.01-5000 \mathrm{~cm} \mathrm{~d}^{-1} \text {, } \\
\text { Inaccuracy: } 2-10 \% \\
\text { KD2PRO: } \\
\text { Resolution / range / accuracy } \\
\lambda: 7 \% / 0.02-2 \mathrm{~W} \mathrm{~m}^{-1} \mathrm{~K}^{-1} / \pm 10 \% \\
\kappa: 7 \% / 0.1-1 \mathrm{~mm}^{2} \mathrm{~s}^{-1} / \pm 10 \% \\
\mathrm{C}: 5 \% / 0.5-4 \mathrm{MJ} \mathrm{m}^{-3} \mathrm{~K}^{-1} / \pm 10 \% \\
\rho: 5 \% / 50-5000 \mathrm{~cm} \mathrm{~K} \mathrm{~W}^{-1} / \pm 0.01 \% \\
\text { Porosity by weighting and drying the } \\
\text { samples of known volume }(250 \mathrm{ml} \text { of } \\
\text { the sample KSAT rings) in an oven } \\
\text { for } 48 \text { hours }\left(105{ }^{\circ} \mathrm{C}\right) \text {. }\end{array}$ & $\begin{array}{l}\text { Summer } 2016 \\
\text { Winter } 2017\end{array}$ \\
\hline $\begin{array}{l}\text { Sediment } \\
\text { structure and } \\
\text { layering }\end{array}$ & Pürckhauer soil borer & $\begin{array}{l}\text { Down to } 1.50 \mathrm{~m} \text { in } \\
\text { the sediment along } \\
\text { the Thalweg of the } \\
\text { stream each } 5 \mathrm{~m} \\
\text { downstream }\end{array}$ & $\begin{array}{l}\text { Qualitative description of type of } \\
\text { material } \\
\text { Approximate description of sediment } \\
\text { layering }\end{array}$ & Summer 2018 \\
\hline
\end{tabular}


Table 2. Interpretation of temperature patterns at the SWI.

\begin{tabular}{|c|c|c|}
\hline $\begin{array}{l}\text { Flow pattern } \\
\text { [Example area] }\end{array}$ & $\begin{array}{l}\text { Temperature anomaly } \\
A_{T}\left({ }^{\circ} \mathrm{C}\right)[\text { Example dates }]\end{array}$ & $\begin{array}{l}\text { Rates of temperature change at the SWI } \\
\text { caused by flood-induced changes of } \mathrm{SW} \\
\text { temperatures } \Delta T / \Delta t\left({ }^{\circ} \mathrm{C} / \mathrm{h}\right)\end{array}$ \\
\hline $\begin{array}{l}\text { Groundwater discharge } \\
\text { [Area GW3/GW4, } \\
\text { Fig. } 2 \mathrm{a}-\mathrm{c}]\end{array}$ & $\begin{array}{l}\text { Permanent cold anomaly }\left(\mathrm{A}_{\mathrm{T}}<0\right) \text { in summer [15 Sep 2016, Fig. 2a/c] } \\
\text { Permanent warm anomaly }\left(\mathrm{A}_{\mathrm{T}}>0\right) \text { in winter [18 Jan 2017, Fig. 2b] } \\
\text { (Quasi-constant permanent temperature anomalies) }\end{array}$ & na \\
\hline $\begin{array}{l}\text { Interflow discharge } \\
\text { [Area INTF2/INTF3, } \\
\text { Fig. 2a-c] }\end{array}$ & $\begin{array}{l}\left.\text { Temporary cold anomaly }\left(\mathrm{A}_{\mathrm{T}}<0\right) \text { in winter [18 Jan } 2017, \text { Fig. } 2 \mathrm{~b}\right] \text { and } \\
\text { summer [2 Jul 2017, Fig. } 2 \mathrm{c} \text { ] with receding extension/intensity after } \\
\text { the end of a rainfall event }[15 \text { Sep 2016, Fig. } 2 \mathrm{a}] \\
\text { (Temperature anomalies increasing in area and intensity: (1) sharp } \\
\text { decrease of T during rainfall event and (2) steady decrease recovery } \\
\text { from hours to weeks scale after the rainfall episode) }\end{array}$ & na \\
\hline $\begin{array}{l}\text { Local SW } \\
\text { downwelling } \\
\text { [Areas delimited } \\
\text { with red contour, } \\
\text { Fig. } 4 \mathrm{~b} / \mathrm{d} / \mathrm{f} \text { ] }\end{array}$ & $\begin{array}{l}A_{T} \approx 0 \text {, i.e. areas with temperatures non-distinguishable from } \mathrm{SW} \\
\text { temperatures }\end{array}$ & $\begin{array}{l}\text { Fast response, with values over the } \\
\text { threshold of } \Delta \mathrm{T} / \Delta \mathrm{t}_{95} \% \text { calculated based on } \\
\text { measurements shortly before the flood } \\
\left.\text { event, e. g. } 1.4{ }^{\circ} \mathrm{C} / \mathrm{h} \text { [25 Jul } 2016 \text {, Fig. } 4 \mathrm{~b}\right] \\
0.8^{\circ} \mathrm{C} / \mathrm{h} \text { [2 Jul } 2017 \text {, Fig. } 4 \mathrm{~d} \text { ], } 0.9^{\circ} \mathrm{C} / \mathrm{h} \mathrm{[3} \\
\text { Jul } 2017 \text {, Fig. } 4 \mathrm{f} \text { ] }\end{array}$ \\
\hline $\begin{array}{l}\text { Local SW upwelling } \\
\text { [Areas outside the red } \\
\text { contour delimiting } \\
\text { areas of local SW } \\
\text { downwelling, } \\
\text { Fig. } 4 \mathrm{~b} / \mathrm{d} / \mathrm{f} \text { ] }\end{array}$ & [All baseflow dates] & $\begin{array}{l}\text { Slow response, with values below the } \\
\text { threshold } \Delta \mathrm{T} / \Delta \mathrm{t}_{95 \%} \text { both under baseflow } \\
\text { conditions [Fig. } 4 \mathrm{~b} / \mathrm{d} / \mathrm{f}] \text { and flood } \\
\text { conditions [Fig. } 4 \mathrm{~b} / \mathrm{d} / \mathrm{f}]\end{array}$ \\
\hline $\begin{array}{l}\text { Temporary emerged } \\
\text { areas }\end{array}$ & $\begin{array}{l}\text { Strong warm anomalies during the daily cycle }\left(\mathrm{A}_{\mathrm{T}}>0\right) \text { when exposed } \\
\text { to radiation [15 Sep } 2016 \text {, Fig. } 2 \mathrm{a}]\end{array}$ & \\
\hline $\begin{array}{l}\text { [Area E1, E1-2, E2, } \\
\text { Fig. 2] } \\
\text { Temporary stagnant } \\
\text { waters }\end{array}$ & $\begin{array}{l}\text { Strong temporally persistent cold anomalies }\left(\mathrm{A}_{\mathrm{T}}<0\right) \text { when affected by } \\
\text { freezing of stagnant waters in winter }[18 \mathrm{Jan} 2017 \text {, Fig. } 2 \mathrm{~b}]\end{array}$ & $\begin{array}{l}\text { Slow with values below the threshold } \\
\left.\Delta \mathrm{T} / \Delta \mathrm{t}_{95 \%} \text { under baseflow [Fig. } 2 \mathrm{~d} / \mathrm{f} / \mathrm{h}\right] \text { or } \\
\text { flood conditions [Fig. } 2 \mathrm{e} / \mathrm{g} / \mathrm{i}] \\
\text { due to clogging. }\end{array}$ \\
\hline $\begin{array}{l}\text { [Area S1, S2-3, S3-4, } \\
\text { Fig. 2] }\end{array}$ & $\begin{array}{l}\text { No anomalies }\left(\mathrm{A}_{\mathrm{T}} \approx 0\right) \text { when connected to streamflow [2 Jul 2017, } \\
\text { Fig. 2c] }\end{array}$ & \\
\hline
\end{tabular}

